\title{
Chapter Four \\ Retreat: Viktor Nekrasov and the Truth of the Trenches
}

Out of his Trenches, as out from under Gogol's "Overcoat," all our honest war prose emerged.

Из его “Окопов", как из “Шинели” Гоголя, вышла вся наша честная военная проза.

-Alexander Parnas ${ }^{1}$

They do it all calmly, with breaks for smoking and joke telling.

И все это спокойно, с перекурами, шуточками.

-Nekrasov, In the Trenches of Stalingrad

"The order to retreat comes as a complete surprise."

Thus begins Viktor Nekrasov's 1946 novel In the Trenches of Stalingrad (V okopakh Stalingrada). ${ }^{2}$ That opening line signalled that In the Trenches of Stalingrad would not follow the usual formula of Soviet war novels. It starts in the middle of the action, and with the most shameful aspect of war: retreat, in this case a retreat that occurred in 1942 during the bitterly fought Battle of Stalingrad.

For our purposes, Nekrasov's novel stands as a pivot between the formulaics of socialist realism and a different way of writing about the experience of war. It introduces a new tone, leaning toward the irony of Vasily Tyorkin and away from the over-earnestness that characterized the official method and that we saw in the heightened metaphors of Kazakevich's The Star. Like Panova's The Train Companions, it revels in the minutiae of daily life, drawing a contrast with the didacticism imposed by commissars and party ap-

\footnotetext{
Alexander Parnas, Tot samyi Nekrasov, excerpted in Kreshchatik 27 (Autumn 2005).

2 According to Nekrasov, the retreat was the portion of the novel about which he was hassled most. On the internal review at Znamia someone wrote the words: "The first pages of the story are not particularly interesting," this despite the fact that they were the first written passage in any genre to discuss the retreat. In the end, the editor, Vishnevsky, left this scene intact. See "Kommentarii tretii", in Viktor Nekrasov, $\mathrm{Na}$ voine i posle (Ekaterinburg: U-faktoriia, 2005), 520.
} 
paratchiks. But with Nekrasov, the reader is in the very trenches, living and experiencing the war along with Soviet soldiers.

In the Trenches of Stalingrad challenges easy notions about the difference between honesty and truth and about the connection between the presentation of facts and the larger meaning of those facts. In these ways, Nekrasov's novel helped create a narrative space about World War II that would later be occupied by writers like Viktor Astafiev, who, in the words of one of Nekrasov's contemporaries, "came out of his Trenches."

No wonder Soviet officials didn't quite know what to do with it.

\section{The Strange Career of Nekrasov's In the Trenches of Stalingrad}

Nekrasov's novel seemed to answer directly the November 1945 call issued to the Central Committee of the Communist Party by F. I. Panferov, senior editor of the journal October:

If a writer were to write of the Fatherland War and dismiss the retreat of the Red Army [to Stalingrad], beginning only with the victorious counterattack, he could not exhibit all the heroism of our country. We do not need a saccharine, comforting literature. We are a nation of great and beautiful truths and are accustomed to looking everything straight in the eye.... ${ }^{3}$

Alexander Tvardovsky agreed when he wrote his reader's report of Nekrasov's Stalingrad for the original journal publication in November 1946:

The first obvious merit of this book is that, deprived of external plot and story enticements, it forces one to read it in one sitting. The palpable authenticity of this testimony about the difficult and majestic days of struggle on the eve of the "great turning point," the simplicity and intelligibility of the narrative, the extremely valuable details of trench life and so on-all these qualities herald unquestionable success with readers. About its essential content the following can be said. This is a truthful story about a great victory that arose from thousands of small, imperceptible gains in battle experience and from the moral and political superiority of our warriors long before the victory resounded

3 Qtd. in Elena Zubkova, Russia after the War: Hopes, Illusions and Disappointments, 1945-1957, trans. and ed. Hugh Ragsdale (Armonk, NY: M.E. Sharpe, 1988), 95. 
across the entire world. This story is also valuable from a literary point of view, original and artistically convincing ...4

It is worth pausing over that review to notice what Tvardovsky has highlighted. "Authentic." "Simple." "Truthful." It would be hard to deny those things. Nekrasov had been there at Stalingrad-he had seen it himself.

Yet those same qualities that Tvardovsky admired seemed to the Writers' Union and official critics to be dangerous, particularly the issue of "truthfulness." Later attacks on Nekrasov accused him of such crimes as "[reveling in] the truth of the trenches," "deheroicization," "slandering," "abstract humanism," and "Remarquism." His work clearly did not follow the official method. As Nekrasov was to recall, in the novel "there wasn't a word about the Party, and only three lines about Stalin." Indeed, Nekrasov claims that at the time he wrote his novel, he did not even know what socialist realism was. ${ }^{7}$

To make matters worse, Nekrasov's own biography cast suspicion on him. Born in 1911, Nekrasov spent several years as a child in Paris with his mother, a doctor. When the family returned to the Soviet Union, Nekrasov grew up in and around Kiev. Of his childhood, Nekrasov recalled "preferring Tarzan's adventures to the Russian classics.” This literary preference, ordinary for a boy if not exemplary for a future member of the Soviet intelligentsia, indicates an adventuresome spirit which would serve the young man well when he found himself in the army. But with a mother like that and foreign

4 Internal review, 8 November 1946, published in Voprosy literatury 10 (1988): 216.

5 L. I. Lazarev, "Nekrasov, Viktor Platonovich," in Russkie pisateli 20 veka. Biograficheskii slovar', ed. P.A. Nikolaev (Moscow: Randevu-AM, 2000), 493. For more on Remarquism, see Georgii Markov, Literaturnaia gazeta 23 December 1962, 1-2, and 26 December, 1962, 1-3, and Iurii Idashkin, “A esli podumat'," Oktiabr' 9 (1962): 212-213. See also Ellis, Vasiliy Grossman: The Genesis and Evolution of a Russian Heretic, 36-37, his "The Problem of Remarquism in Soviet Russian War Prose," Scottish Slavonic Review 11 (1988): 91-108, and Rosalind J. Marsh, Soviet Fiction since Stalin: Science, Politics, Literature (Totowa, NJ: Barnes and Noble Books, 1986), 197-198. Ellis identifies Remarquism as one of his five categories for exploring war literature in his The Damned and the Dead: The Eastern Front through the Eyes of Soviet and Russian Novelists.

6 Nekrasov, V okopakh Stalingrada (St. Petersburg: Azbuka-Klassika, 2005), 441.

7 "V okopakh Stalingrada," radio speech, 12 October 1985. "This man now knows perfectly well what Socialist realism is. Perhaps that's the very reason he left his native Kiev. Just as Aksyonov, Voinovich, Vladimov, Gladilin, Maksimov, Brodsky, Dovlatov-I may have missed someone-left their Moscow or Leningrad. And now they write whatever they like and there is no censorship hanging over them ..." Published in Nekrasov, $\mathrm{Na}$ voine i posle, 516. 
tastes to boot, Nekrasov made an unlikely orthodox Soviet patriot. An easy decision, then, when Alexander Fadeev, head of the Writers' Union at the time, crossed the novel off that year's Stalin Prize list before passing the list to Stalin for final approval.

Stalin put the novel back on the list. In his address to the Soviet people at the end of the war, Stalin had given the people, not the party, credit for winning the war: "The address contained not a word of the party and its role in the organization of victory. Stalin simply excluded this intermediary link between himself and the people." Znamia editor Vsevolod Vishnevsky told Nekrasov that "Stalin himself personally gave the author this most prestigious literary prize."

In awarding the prize, Stalin circumvented the party and bureaucratic apparatus, celebrating Nekrasov, whose novel had also left the party out of the victory, perhaps precisely rewarding the author-veteran for his "in the trenches" emphasis on the people. Historians have called Stalin's move an "inexplicable caprice" that saved Nekrasov's work from the denunciation planned for it by the Writers' Union. An ironic episode of de-Stalinization by Stalin himself.

It is hardly worth speculating about why Stalin decided to do what he did. It may be that Nekrasov was simply the right man in the right place at the right time and it was convenient to forget his family connections.

Here he was-a junior officer, a battle participant, Russian, twice wounded, with an imposing physical appearance that matched the 1940s aesthetic, a Party member (he joined during the heat of the Stalingrad battle on Mamaev Kurgan) - in the euphoria of victory all of this facilitated the novella's publication. ${ }^{9}$

It may very well have been part of Stalin's specific plan to decimate the literary hierarchy and start again with young authors. Nekrasov certainly

8 Georgii Baklanov, "Vozvrashchenie," V okopakh Stalingrada (Moscow: Khudozhestvennaia literatura, 1990), 29.

9 Lazarev, "Nekrasov," 492-93. After the war, Nekrasov himself was not particularly patient, especially when it came to bureaucracy and protocol. Wanting to continue his education at the construction institute, Nekrasov brought several pastels he had made of the bombing of the "Red October" factory during the siege of Stalingrad to the examination committee, hoping to impress them. When they suggested that he gain some experience by working as a draftsman for a while, he relates, "I didn't bother to wait. I got drunk and became a journalist." See "Stalingrad, October 1942," in Viktor Nekrasov, Na voine i posle, 535. 
remained puzzled by the prize and later imagined what might have gone on in Stalin's head: “They are all rogues. All! Every one. With that drunk Fadeev at the head of the whole bunch. ... Things are bad with the writers, bad. I arrested all the good ones, and the new ones are not keeping up. ..." ${ }^{10}$ One way or the other, the prize helped rocket the novel to great success. In the Trenches saw more than 130 reprintings between 1947 and 1974.

At which point the novel was unceremoniously banned, and its author, expelled from the Communist Party, emigrated to France. His biography, and his outspoken nature, became too uncomfortable for the Soviet government and the Communist Party. Only when the Communist regime was coming to an end could he be praised again in Russia. And when a new edition of In the Trenches of Stalingrad came out in 1990, Grigorii Baklanov lamented in the introduction the generations who had missed out on the novel. "All those years it was as though the novel did not exist, but it did exist and it remains the pride of our literature."11 Nekrasov could not share in this renewed pride; the author had passed away in Paris in 1987.

During World War II, Nekrasov was a sapper, part of a crew working with land mines at the Battle of Stalingrad. His novel about the battle was published by Vishnevsky in his journal Znamia in 1946 under the title Stalingrad. ${ }^{12}$ An unsparing portrayal of the horrors of war and the complicated relationships among soldiers during wartime, the narrative was based on the author's own experiences of war, the experiences of an eyewitness and a participant. But Nekrasov transformed those experiences, brought them to life for his readers. His incredible eye for detail and use of the "in the trenches" point of view changed the genre of war fiction for Russian literature.

There was something different in In the Trenches, something that Nekrasov's contemporary readers felt instinctively. Readers frequently praise the

10 See V. A. Potresov, "Vozvrashchenie Nekrasova," in Viktor Nekrasov, Zapiski zevaki (Moscow: Zakharov, 2003), 17-18 and Nekrasov, Saperlipopet. Esli b da kaby, da vo rtu rosli griby (London: Overseas Publications, 1983).

11 Baklanov, "Vozvrashchenie," 6. The Posev edition includes a note from the publisher about the original novella, which had become a "bibliographic rarity" due to being blacklisted in the Soviet Union. See Viktor Nekrasov, Stalingrad (Posev: Frankfurtam-Main, 1981), 6.

12 As Nekrasov liked to point out in later years, Vishnevsky "was a living classic, one of the most influential leaders of the Writers' Union, a person experienced in all things, who knows what is what, what is possible and what is forbidden" (Nekrasov, Stalingrad, 1981, qtd. 441). 
book as one of the most "truthful" narratives about the experience of World War II. Among others, Lev Kopelev regarded In the Trenches of Stalingrad as his first and favorite book about the war, a book that told the "truth about the war that we cannot and do not want to forget, the bitter taste of which is still alive in us today." 13

Intonation was the key to most readers' reactions. Fellow exile Efim Etkind described Nekrasov's intonation as "living, natural, like breathing." Told mostly from the point of view of its main character, Lieutenant Kerzhentsev, In the Trenches of Stalingrad avoids all loftiness, all pomp and pathos, relying instead on straight talk, frank descriptions, small details. In their 1946 novellas, both Panova and Kazakevich-also eyewitnesses to war-summed up, made larger judgments about the meaning of the events they experienced, even in Kazakevich's case resorted to dramatic allegory, but Nekrasov refrained from any generalizations. In memoirs addressed to Nekrasov, Etkind recalled:

In an era of loud voices, journalistic eloquence and noisily shouted slogans you began to speak slightly ironically and with a deliberate masculine roughness from which tenderness peeked out. [ ... ] You wrote about what is often called a soldier's heroism as if it were the daily behavior of regular guys. Your gentle mocking restraint conquered everyone-then, in 1946, with your Stalingrad you inaugurated a new era in literature: the sound of the truth that is born on the edge of life. [ ...T] he truth of masculine solidarity, of daily life in the trenches, and of soldiers' friendship was heard in the intonations of your book. ${ }^{14}$

The fact that Nekrasov drew from his own experiences certainly contributed to a sense of authenticity in the novel and to the "truthfulness" that readers found when they read it. The book neither hid nor apologized. ${ }^{15}$

13 Lev Kopelev, "Pervoe znakomstvo," in "Iz knigi druzei-Viktoru Nekrasovu. Vospominaniia o pisatele," in Vremia i my 98, ed. Efim Etkind (New York, Jerusalem, Paris: Vremia i my, 1987), 224.

14 Efim G. Etkind, "Intonatsiia," in "Iz knigi druzei," 214-215. Other critics grouped a number of books together as a "new wave of literature about war," including Grossman's Stalingrad sketches, Kazakevich's Star, Panova's The Train Companions, and Tvardovsky's Vasily Tyorkin. See I. Vinogradov, “Chelovek i voina," in Viktor Nekrasov and Iurii Bondarev, V okopakh Stalingrada and Poslednie zalpy (Moscow: Izvestiia, 1968), 470-95; 470.

15 Eisenstein referred to the novella as the "diary of an officer." The style was frequently called "diary-like": "with short phrases, present tense, the author telling only about what he sees, with no literary 'fanciness." See Potresov, "Vozvrashchenie Nekrasova," 15. 


\section{Investing War with Meaning}

The plot of In the Trenches of Stalingrad does not follow a conventional arc but rather reads like a set of adventures as the protagonist Lieutenant Yury Kerzhentsev moves from one battalion to another across the front near Stalingrad. Important individual events include retreats, a taste of civilian life, attacks, waiting periods, and even disagreements about tactics that lead to a court-martial. Throughout it all, Kerzhentsev tries to find a balance between following orders and doing what makes sense.

Kerzhentsev acts as the first-person narrator; the events of the novel are filtered through his consciousness. In the service, Kerzhentsev is an engineer, though like his creator, Nekrasov, he had studied to be an architect in his native Kiev. Over the course of the novel, Kerzhentsev and his fellow soldiers retreat in a sloppy line toward Stalingrad, spend some amount of time in that peaceful city, watch its partial evacuation, and dig in to defend it. The novel ends with a discussion of Adolf Hitler's Stalingrad speech and the soldiers' musings on why the battle turned out as it did, with the Germans smashed and in retreat and the Russians battered but victorious. ${ }^{16}$

As the narrative begins, Kerzhentsev heads to Stalingrad after a disorganized retreat from a failed defensive position near Voronezh. He hopes to meet up with his battalion there. In Stalingrad, he and his buddy Igor Svidersky experience civilian life: taking tea, walking through the city, visiting the public library. Soon, though, the Germans attack, and Kerzhentsev is assigned to a group that occupies the tractor factory, preparing to blow it up if necessary. These days in the factory illustrate the experience of waiting in wartime, and a certain routine, calm, and even boredom set in.

That routine is interrupted as Kerzhentsev is moved to active positions near the Volga River, where he constructs his entrenchments and works with a small battalion, taking over when the commander is killed. He and his group storm the Mamaev Kurgan hill, but he is relieved of his command when a new man is appointed. Their position is a dangerous one, as they are surrounded, and eventually they are able to escape with serious losses. Other battles ensue. When the head of the division, Captain Abrosimov, insists that they launch a direct attack, Kerzhentsev goes into battle with his fellow soldiers. Half their battalion is lost, including Kerzhentsev's comrade Nikolai Karnaukhov, and in the aftermath Abrosimov is court-martialed and sent to a penal battalion.

16 Nekrasov had planned a third part, but the book was rushed into publication without it. He added part III in 1971. Only the originally published two parts are under discussion in this chapter. 
Hoping to maintain a semblance of real life, Kerzhentsev and his comrades try to mark his birthday on November 19, but those celebrations keep being put off by urgent military actions, until finally the lieutenant is wounded and ends up in a medical battalion. The novel ends with him returning to Stalingrad to discover that Igor, from whom he had become separated, is still alive, but before they can be reunited, another attack begins.

The novel is more than the sum of its events. As Vladimir Zubkov has written:

The author of In the Trenches of Stalingrad addressed [...] the problems which would in future constantly feed war prose: the traces of prewar life in the consciousness of the frontline soldier, the internal freedom and conscience of the fighting man in the face of the commander who has been deprived of moral reins by the authorities, the indissoluble nature of the individual person and its trace in the general victory. ${ }^{17}$

It was this inner truth, this portrayal of the fighting man as an individual with a past and a part to play in the future, with feelings and desires and reactions to things that were happening around him, that made his novel popular among contemporaries, particularly those who had fought themselves. Nekrasov dismissed praise and accolades that he had written the "best novel about the war." In conversation with Lev Kopelev, for example, Nekrasov insisted:

"I know, I know, I've heard that before. Were you at the front? ... Then how the hell, comrade Major, can you say that mine was the "best novel about the war'? You must know that it only contains part of the truth." "Maybe only part, but not a word of nonsense..."

"Perhaps... . But partial truth is also nonsense." 18

This is more than just semantic games, trying to parse the difference between truth, partial truth, and nonsense. This exchange between Nekrasov and Kopelev takes us directly back to the fundamental problems of how to turn war into narrative, which we discussed in the introduction to this book.

Call it a problem of altitude. Wars must be given meaning in order that they can be justified. To create that meaning requires a writer to see the total-

17 See "Ozhidanie? Proshchanie? Segodnia i zavtra khudozhestvennoi prozy o Velikoi otechestvennoi voine," Ural 5 (2010).

18 Kopelev, "Pervoe znakomstvo," 221. 
ity of the conflict, the grand purpose, to see it, as it were, from high above. For soldiers on the ground, it is virtually impossible to see that totality and thus to construct larger meaning from their own very limited experience. Nekrasov understood this full well: "In war," Nekrasov's hero tells the reader, "you never know anything except what's going on under your very nose" (V okopakh Stalingrada, 16).

That dilemma has been true for all writers trying to narrate all wars, starting with Homer. Nekrasov, however, stands as one of the first Soviet writers to confront it and the first to tell the story of war from underneath his nose. His book is as powerful as it is because he does not try to see the war from the heights, from an altitude that would give the events greater meaning. Instead, he stays in the trenches, and he demonstrates that meaning happens precisely in the trenches, in daily conversations and relationships between individuals.

\section{Duty and Daily Life}

The "truth of the trenches," as Nekrasov created it, represents a shift from the truth we saw in Tvardovsky's Vasily Tyorkin. Tyorkin was part of the visual as well as verbal vocabulary of the war, helping with his cheerful smile and energetic approach to battle to further the propaganda efforts of wartime writers and artists. Through posters and images, as well as in the newspaper publications of Tvardovsky's chapters, Tyorkin and other epic characters put poetry and pictures to work for the state. ${ }^{19}$

But that wartime balance, in which the details of byt in Tyorkin were augmented by heroism, by the rhetoric of podvig, changed after the war. As a witness and participant, Nekrasov was writing for a different audience, no longer for the warrior who needed to keep his spirit up, but for veterans and civilians like himself who were processing the events and effects of the devastating four-year war. In Nekrasov's prose, the rhetoric of podvig was replaced by the rhetoric of est', describing how soldiers did their duty in the mud and blood of wartime whether they wanted to or not. ${ }^{20}$

19 For more on this, see Bird, "The Functions of Poetry."

20 Ellis calls this "heroic pragmatism." Zubkova comments that "soldiers' letters and diaries often represent the experience of the front not in the usual halo of heroism but simply as an ordinary, stressful kind of life, the most terrible part of which was death. As people gradually grew accustomed to this new life, it was not the new but the old prewar life that seemed strange and unimaginable" (Zubkova, Russia after the War, 15). 
His focus on the quotidian, the everyday, made that duty feel like a real process, a set of decisions and compromises that matched the actual soldier's experience; and with the ironic tone of his first-person narration, Nekrasov reflected many soldiers' ambiguous feelings about what they had done. Irony gave them back their individual right to have an opinion about their own actions, those of their comrades, and those of their commanders. Irony allowed them to feel like human beings, not just automatons performing feats.

The defensive nature of most of the military action in the novel means that Kerzhentsev and his fellow soldiers spend more time smoking, chatting, digging, and planning than they do attacking or actually fighting. Indeed, as the narrator complains:

The most terrible thing about war is not the shells, not the bombs, one can get used to all that; the most terrible thing is the inactivity, the uncertainty, the lack of an immediate goal. (Vokopakh Stalingrada, 60)

The novel offers evidence of this observation about wartime, that most of it is spent without purpose or direction. We can compare this feeling with the porozhny reis described by Vera Panova, which we explored in the previous chapter; after all, her "empty trips" in the hospital train were also a break, a time of inactivity. But perhaps because the empty trips rhymed with trips full of activity, gruzhyony reis, and because during those times the train was in motion back toward the front, for Panova's characters those empty trips did have a purpose and direction. For Nekrasov's Kerzhentsev, especially at the beginning of the Stalingrad campaign, the waiting and not knowing seems more terrible than death.

The pace of the story allows Nekrasov to share with us the musing and philosophizing that goes on during these interminable periods of "uncertainty" and provides us with plenty of details of everyday life in the trenches and even in the city. Nekrasov's language is also the language of byt, of everyday life, with informal vocabulary and diction to match the informal interactions between soldiers. With the action being described in the present tense, the reader experiences the frustration, fear, boredom, and panic along with the characters. In his fiction, Nekrasov narrates the war from the inside, offering the reader the feeling of being at the front, experiencing the same priorities and emotions that soldiers experienced. 
As a narrator and main character, Kerzhentsev is highly observant, with many of his characterizations arresting in their degree of perception. Sudden, unexplained changes in military strategy abound, and in the narration they can seem as random and disconnected for the reader as for the characters. Indeed, it is telling that the novel opens with the "order to retreat." In chapter 2 , the narrative catches up with this surprise order:

Life was flowing calmly and evenly. Even "Pravda" had begun to reach us from Moscow. There were no losses.

And suddenly like snow on our heads-an order....

You never know anything in war except what is happening under your very nose.

When the Germans aren't shooting at you-it seems to you that over all the world peace and silence reign; when they begin to bombyou are immediately certain that the whole front from the Baltic to the Black Sea has begun to move. (V okopakh Stalingrada, 16)

Such musings are paired in the novel with small events, events that move the reader in and of themselves and also stand for something more. For example, when a few shells do reach the soldiers during this first retreat:

A shard wounds the orange cat who has been living with her kittens in our basement. The first-aid officer binds her wound. She meows, looks at all of us with fearful eyes, and climbs into the box with her kittens. They squeak, crawl on top of each other, and butt at the bandage with their little faces, but they cannot find her nipples. (V okopakh Stalingrada, 18)

The little family of cats serves as an understated metaphor for the mutual dependency of soldiers at the front.

This theme of mutual dependency, the need for other human beings to share experiences and to help motivate action in wartime, is brought out more overtly through the introduction of an officer named Maksimov, who impresses Kerzhentsev early in the novel. When he asks the soldiers whether or not they are married and receives a negative reply, Maksimov responds, "Too bad. I'm not married either, and now I regret it. A wife is essential. As necessary as air. Especially now. ..." (Vokopakh Stalingrada, 14). During the retreat, the unit is surrounded by German troops, and most of them perish, including Maksimov. 
Vasily Grossman wrote a journalistic account of the same retreat:

Those were hard and dreadful days. . . The armies were retreating. Men's faces were gloomy. Dust covered their clothes and weapons, dust fell on the barrels of guns, on the canvas covering the boxes full of headquarters documents, on the black shiny covers of staff typewriters, and on the suitcases, sacks and rifles piled chaotically on the carts. The dry, grey dust got into people's nostrils and throats. It made one's lips dry and cracked.

That was a terrible dust, the dust of retreat. It ate up the men's faith, it extinguished the warmth of people's hearts, it stood in a murky cloud in front of the eyes of gun crews. (A Writer at War, 130-131)

Grossman's dust evokes the hopelessness of this period of the war. He creates useful and highly descriptive generalizations. But Nekrasov does the same thing, without the summing up, with his cats and his lonely officers who wish they had married in time.

Explicit comparisons of the soldier's life and civilian life emerge in chapter 3, which is filled with recollections. By the "shimmering light of the rockets," Kerzhentsev falls into reminiscences of his street, the chestnut trees of Kiev, and the large soft sofa in his childhood home.

After dinner grandmother always rested [on that couch]. I would cover her with an old overcoat, which served only this purpose, and give her a book of memoirs or Anna Karenina. Then I would look for her glasses. They would turn out to be in the buffet, in the spoon drawer. By the time I found them, grandmother would already be sleeping. And the old cat Fracas with his singed whiskers would squint from under the flaking collar [of the coat]. ... My God, how long ago that was! ... Or perhaps it never happened, but it only seems like it did.... (V okopakh Stalingrada, 19)

The young soldier recalls his mother, his "dear, beloved Kiev," his group of six inseparable friends. Ten months have passed since his last postcard from his mother, the same ten months since Kiev fell to the Germans. While he is performing his duties, mining the territory the army has left, Kerzhentsev gives himself over to these recollections, even mentally walking along the peacetime streets of his town, one at a time, remembering landmarks and 
events connected with them. He muses on what has happened to his friends from the institute:

Chizhik perished near Kiev, at Goloseev. [...] both of his legs were torn off. I don't know anything concrete about the rest. I think Vergun was captured. Rudensky was not mobilized-he's near-sighted-and I think he was evacuated. He saw me off at the station when I left. I heard from someone, I don't remember who, that Anatoly became a communications officer. And Lyusya?... Perhaps she was evacuated? Doubtful.... She has an old, sick mother. (V okopakh Stalingrada, 22-23)

Now, in wartime, Kerzhentsev has to form a new collective from the soldiers with whom he lives and fights. He even finds a new Lyusya in Stalingrad, though when the opportunity arises he refuses to kiss her, remaining loyal to his old friend instead. Thus, what Catherine Merridale has called "the spirit that emerged at Stalingrad" is in the novel precisely a military brotherhood, a collective based on shared experience.

But at the same time, Nekrasov makes clear in the narrative that Kerzhentsev's relationships with friends and comrades in the army-and his movements within the physical landscape in and around Stalingrad-are built on personal relationships and spatial memories from his pre-war life. The juxtaposition of the two chronotopes, wartime life in the trenches and peacetime in Kiev, strengthens both. Merridale has argued that "the party took the credit" for this Stalingrad spirit, but in Nekrasov's narrative his hero's actions and thoughts during wartime did not differ greatly from those of his pre-war self. ${ }^{21}$

One of the strongest relationships Kerzhentsev forms is with his eighteenyear-old orderly, Valega. ${ }^{22}$ Described in diminutives (a remarkable little guy, small, and round-headed [zamechatel'nyi parenek, malen'kii, kruglogolovyi]), Valega is a loyal servant, child, and wife to Kerzhentsev.

21 "The brotherhood and selflessness to which the [Stalingrad] battlefield gave birth were rapidly adopted as the offspring of its ideology, its wise guidance. 'Thousands of patriots are proving themselves to be models of fearlessness, courage, and selfless dedication to the motherland, the soldiers' front-line paper crowed" (Catherine Merridale, Ivan's War: Life and Death in the Red Army, 1939-1945 [New York: Metropolitan Books: 2006], 179). In contrast, In the Trenches portrays an entirely different source for the soldiers' bravery and comradeship.

22 This relationship was highlighted in the 1956 film made from the novel, Soldiers (Soldaty). 
He knows how to cut hair, shave, repair boots, start a fire even in pouring rain. Every week I change my undergarments, and he darns socks almost like a woman. When we're stationed near a river-fish every day, in the forest-strawberries, blackberries, mushrooms. And everything silently, quickly, without any suggestions from me. In all nine months of our life together I have never had to get angry with him. (V okopakh Stalingrada, 26)

Kerzhentsev comments that he does not know much about Valega, merely that he is from Altai-a region in South-Central Siberia-and was orphaned as a child. Sentenced for a minor criminal offense, Valega was released early and volunteered for the war. ${ }^{23}$ The boy's actions throughout the narrative demonstrate his loyalty and concern for Kerzhentsev; with his ubiquitous flask of milk and flask of vodka, Valega several times sneaks through enemy lines to supply these, or water, to Kerzhentsev and his fellow soldiers. As Alexander Prokhorov has noted, between Valega's sock darning and his jealousy when Kerzhentsev interacts with another orderly, Valega serves as the "necessary wife" for the narrator, feeding him, clothing him, and watching his back. At the same time, Kerzhentsev is a father figure to the fatherless Valega. ${ }^{24}$ These pseudo-family relations again link peacetime and wartime through the common psychological and human needs of the characters.

Because he hails originally from Altai, Valega serves another purpose here as well-geographic and social diversity. Where else might a boy from the Kievan intelligentsia meet a peasant from the Far East but at war? One of the remarkable but incidental outcomes of the Soviet war experience was to bring a wide cross section of the Soviet empire together in common pur-

23 Nekrasov notes that this is the only character in In the Trenches whose name he did not change; Valega was his orderly during the war and he continued to maintain a relationship with him and even wrote about him (in Tri vstrechi). See "Kommentarii vtoroi," in Viktor Nekrasov, Na voine i posle, 519-520. When Nekrasov and the actor Iura Solov'ev went to Altai to show the film "Soldiers," Valega was asked to speak. "Here is what he said, word for word: 'Well, how did we fight? Bit by bit. We placed mines, Bruno spirals, dug trenches. That's how we fought. Thank you"' (Nekrasov, Na voine i posle, 519).

24 In another place, Kerzhenstev compares Valega to his mother, who used to hand him French rolls with butter as he headed out the door to school. As Kerzhentsev gets ready for the nighttime attack on Mamaev Kurgan, Valega begs, "Perhaps a bite to eat for the road? I have canned goods. Canned meat. You didn't even have a proper dinner. I'll open some," but Kerzhentsev refuses, so Valega shoves a piece of bread and lard, wrapped in newspaper, into his pocket (V okopakh Stalingrada, 180). 
pose. ${ }^{25}$ In one sentence in the middle of the story, Nekrasov introduces us to "Shapiro, Pengaunis, Samoilenko, and Sedykh," signaling a Jew, a Lithuanian, a Ukrainian, and a Belorussian. On the front lines and in the rear, Russian and Soviet people from the village and the city, from the university and fresh from the Gulag met in the army during wartime. This truth in wartime became a convention of Soviet military fiction. In The Star, for example, the reconnaisance group is made up of people from various parts of the Soviet Union, demonstrating that in wartime the "friendship of the Soviet peoples" helped them beat the racist and "racially pure" Nazi forces.

Almost the first thing Kerzhentsev notices when he reaches Stalingrad is the loudspeaker, over which Chekhov's story "Vanka" is being read. The plaintive (and hopeless) notes of Vanka's letter "to grandfather in the village" remind Kerzhentsev of the culture of pre-war civilization, as do the signs of normal life around Stalingrad:

Blue skies. And dust... And slender acacias, and little wooden houses with carved roosters, and "Do Not Enter-Fierce Dogs." And nearby large stone buildings with female figures supporting something on the facades. The office of "Lower Volga Kooppromsbyt," "Patching of Galoshes," "Primus Repair," "The Molotov Regional Procurator's Office." (V okopakh Stalingrada, 56)

The inclusion of Chekhov in the story is a nice touch, a reminder of both high and popular culture. The story read over the radio of the indentured peasant boy-alone and lonely, out of place and out of his element, with no hope of rescue-reminds civilians and soldiers alike of the despair of pre-revolutionary life. In literary terms, though, Chekhov more than any other writer underscores what Nekrasov is trying to accomplish with In the Trenches. After all, no Russian writer better conveyed life bounded by inactivity and uncertainty, and Chekhov's detail-saturated, realistic prose, like Nekrasov's, lacks the "altitude" of the bigger picture.

When Kerzhentsev and his friend Igor arrive in Stalingrad, fresh from the disastrous retreat and now lacking a regiment, they find civilian life and discover that their attitude toward it has changed. Trying to chat with Igor's former commander's sister, Lyusya, Kerzhentsev realizes that the vestiges of culture no longer interest him:

25 As Zubkova has written, "The war created its own special mode of association for people whose paths during peacetime rarely crossed" (Russia after the War, 17). 
For some reason I don't feel right, and I don't want to talk about Blok or Esenin. All of this did once interest and concern me, and now it has retreated far, far into the distance. . . . Architecture, painting, literature ... I have not read a single book since the war started. And I don't want to, I don't feel like it. All of that is for later, later. ... (V okopakh Stalingrada, 65)

Though while in the trenches Kerzhentsev has dreamed of moments such as he now experiences with Lyusya-drinking tea, sitting on a couch, and listening to her play Liszt on the piano-these activities now make him uncomfortable. "After all, I'm no deserter, no coward, no hypocrite, but I feel somehow as if I were...." (V okopakh Stalingrada, 60).

The military way of life has usurped civilian life, and Kerzhentsev feels a sense of betrayal in enjoying the beautiful while recalling the horrors of warthose behind him and those to come. Duty comes first, and though the city is in the midst of a period of inactivity, the feeling makes Kerzhentsev uneasy. During a trip to the city library, Kerzhentsev describes the comfortable woven chairs, the portraits of Turgenev, Tyutchev, "someone else with a mustache and a tiepin, some kind of Peruvian novellas from International Literature." These comforts of civilized life, the life of an intellectual, lure Kerzhentsev, and at home in his little room Valega has reheated a delicious borscht soup. But the narrative insists that this former reality, those peaceful days, are gone.

The city is filled with the sounds and smells of the first serious German air raid. Kerzhentsev's little room dissolves into dust, with shards of dishes and clumps of asphalt mixing with and destroying the borscht of which Kerzhentsev hasn't yet taken a spoonful. Peaceful life is over; the siege of Stalingrad has begun.

Kerzhentsev and Igor Svidersky (and their orderlies, Valega and Sedykh) are assigned to defend a tractor factory. Here they essentially prepare to blow the factory up, and in the meantime they have plenty of down time for reading and conversation. "We begin to make ourselves at home in our bunker": Valega and Sedykh decorate their little corner with a portrait of Stalin, a postcard of the Odessa Opera Theater, and a reproduction of Repin's Zaporozhians. Sedykh, who turns out to be a rather interesting young man, finds three books: Kruber's geography textbook, a volume of Chekhov's letters, and an issue of the magazine Niva from 1912. Kerzhentsev notes that "Sedykh is so curious as to be amusing," asking the most unexpected and naive questions and listening 
to the answers "as children do a fairy tale" (V okopakh Stalingrada, 93), reminiscent, perhaps, of the naïve Vanka from Chekhov's story, the peasant boy thrown into unknown circumstances and longing for a clear narrative. Here, in the comfortable atmosphere of the bunker, a conversation about "heroes and medals" ensues. Upon learning what is necessary, Sedykh decides, "That's it. I'll get a medal." As if such decisions, ultimately, were his to make.

\section{War Heroes in an Industrial Age}

World War II was a war fought on an industrial scale. We saw earlier in the propaganda of hatred promulgated by war journalists and poets, including Simonov and Ehrenburg, that the Germans were being portrayed as inhuman, as barbaric. They were also portrayed as machines, part of the new industrialized warfare that featured fighter planes and tanks rather than cavalry and infantry. ${ }^{26}$

At one point in the middle of Nekrasov's novel, three characters have an exchange about the war, about why they fight it, and about who they are. Kerzhentsev's fellow officer Igor takes the opportunity to puff his chest about the unbreakable mettle of the Russian people:

France basically fell apart in two weeks. They pushed, and it fell into ruins, dispersed like sand. But we are fighting for the second year already ... [In France they have] Petains and Lavals. And we don't have those sorts. That's the main thing. Do you understand that that is the main thing? That our people are of a different sort. And that's why we're fighting. Still fighting. Even here, on the Volga, having lost Ukraine and Belorussia, we're fighting. And what country, tell me, what country, what people could withstand this? (V okopakh Stalingrada, 95)

But another member of the group argues that the outcome of war no longer depends on the strength of "the people," on the national ideal of the Russian warrior. Georgy Akimovich argues that modern war has become bigger than any people:

Everything needs to be considered soberly. You can't do anything with heroism alone. Heroism is heroism, but tanks are tanks. [Geroistvo

26 For a great collection of images of these hated foes, as well as images chronicling Soviet-American friendship during the war, see Jill Bugajski, "Paper Ambassadors: Friend and Foe in the War of Images," in Windows on the War, 104-135. 
geroistvom, a tanki tankami.] [. . .] We will fight to the last soldier. Russians always fight like that. But nonetheless we have little chance. Only a miracle can save us. Otherwise we will be crushed. Crushed by organization and tanks. (V okopakh Stalingrada, 96-98)

Georgy Akimovich does not see the German soldiers as individuals: they are machines designed and destined to mow down their Russian enemies. Heroics, he argues, can only take the Russians so far. They will need technology and organization-in other words, a miracle — to prevent a massacre.

Kerzhentsev has an answer for Georgy Akimovich, though he keeps it to himself (and tells only the reader). Overhearing a song about the Dnieper River and a conversation between two privates about the rich, fertile soil of their homeland, Kerzhentsev muses:

There are details which you remember all your life. And they aren't just the memorable ones. Little, almost insignificant, they eat their way into you, become a part of you somehow, begin to grow, to grow into something big and significant, they take upon themselves the entire meaning of events, become something like a symbol. [. . .] Tolstoy called this the hidden warmth of patriotism. That may be the best definition. Perhaps this is the very miracle which Georgy Akimovich is expecting, a miracle that is stronger than German organization and tanks with black crosses. ${ }^{27}$

Reaching back across Russian literature and history, Nekrasov does not simply tie his novel (and the experience it details) to Tolstoy's War and Peace. After all, for Kerzhentsev, as the reader already knows, the Tolstoy who wrote Anna Karenina has no meaning in the trenches of Stalingrad. But the other Tolstoy, the one who knew about war and patriotism, speaks to him now. ${ }^{28}$ Kerzhentsev and his comrades are sustained not by the party, or by the thought of Stalin, but by that "hidden warmth of patriotism."

27 V okopakh Stalingrada, 99. There were half a million troops massed for the defense of Stalingrad in the summer of 1942. Over three hundred thousand of them would die defending the city. Cited in Merridale, Ivan's War, 174.

William Nickell quotes an apt saying from the magazine Vlast' truda: "To Tolstoy the writer: peace / But to Tolstoi the prophet: war!" For our purposes it is the novelist of peace who is alien, while the novelist of war speaks to Kerzhentsev. Quoted in "Tolstoy in 1928: In the Mirror of the Revolution," Epic Revisionism (Madison: University of Wisconsin Press: 2006), 17. 
This exchange, in which Tolstoy gets the last word, underscores that In the Trenches does not even pretend to adhere to the doctrine of socialist realism. Stalin makes several appearances in the novel, and a portrait of Stalin was one of the symbols of comfort and home at the tractor factory. But as Nekrasov noted, in all there were "only three lines about Stalin."

\section{Individual as Heroic}

We have defined Soviet heroism as bravery plus consciousness. However, in the second part of In the Trenches, we meet a character who introduces the reader to a different version of heroism. Nikolai Karnaukhov has recently returned from a month-long hospital stay to take the place of the now-dead commander of the fourth battalion. "Tall, pigeon-toed, with thick brows that met in the middle, gray-eyed," Karnaukhov speaks slowly, in a deep voice, carefully choosing his words. An efficient leader, Karnaukhov keeps his dugout very clean and neat ("ne po-frontovomu") and, what's more, appears to write poetry (V okopakh Stalingrada, 150-151). Brave and modest, Karnaukhov has also decorated his wartime lodgings:

On the wall hung a calendar with days crossed out, a list of radio signals, a portrait of Stalin cut out of the newspaper, and of someone else-young, curly-headed, with an open, kind face.

"Who is that?"

Karnaukhov, catching my eye, looked bashful.

"Jack London."

"Jack London?

Karnaukhov is standing in the light, I cannot see his face, but by his translucent ears I can see that he is blushing.

"Why Jack London all of a sudden?"

"It's just. ... I respect him.... Well, and. ... Would you like some milk?” (V okopakh Stalingrada, 155)

It turns out that while in the hospital, Karnaukhov was reading everything he could find, and he did not have time to finish London's novel Martin Eden, so he took it with him. The conversation continues:

"Do you like Jack London?"

"Yes, I've read him several times."

"I like him too." 
"Everyone likes him. It's impossible not to like him."

"Why?"

"He's real somehow. ... Even Lenin liked him. Krupskaya read him aloud." (V okopakh Stalingrada, 156)

The novel Martin Eden-London's semiautobiographical story of a self-educated, hardworking sailor who learns proper manners and grammar from a beautiful, young, college-educated bourgeois woman and then passes her by in sophistication, knowledge, and style - was published in 1909. A compelling and exciting narrative, the novel features a hero almost akin to Chernyshevsky's Rakhmetov in his asceticism and determination, whose loyalty to family and the lower classes despite his growing awareness of their limitations and his anger at his own disadvantage is matched only by his intellectual curiosity and incredible physical stamina. Kerzhentsev asks to borrow the novel when Karnaukhov has finished.

Eden's regime, which involves hard, intellectual labor nineteen to twenty hours a day (he only allows himself four to five hours of sleep), matches the labor of the men at the front line. As Kerzhentsev comments of Karnaukhov, "I know that he, like I, wants more than anything to sleep. But he will still sit down and draw the design of his defenses, sticking out the tip of his tongue, or he'll run to check whether dinner has been brought to the sergeants" ( $V$ okopakh Stalingrada, 151). Duty comes first.

This short conversation about fiction-very general, after all, with appropriate political approval from the father of the party-is not the end of Martin Eden in the trenches. Later on in the narrative, one of their superior officers, a colonel and the division commander, also notices the book lying on a table. Paging through it, he glances at the end and "furrows his brow in dissatisfaction": "Idiot. Dear Lord, what an idiot." The colonel had read the book long ago and has forgotten it. "I only remember that the young man was stubborn. And I don't like the end. It's a bad ending."

Suddenly, and without explanation, the colonel is assigning Martin Eden as reading material, not only to Kerzhentsev, but to Borodin, another soldier. "Then I'll organize an exam. Like we have on service regulations. We have a lot to learn from this Martin. Doggedness, persistence" (V okopakh Stalingrada, 167).

The colonel's insistence on this required reading is highlighted by the command he gives Kerzhentsev. Although Kerzhentsev and his men have 
been fortifying the area with mines, the colonel insists they attack Mamaev Kurgan, the famous hill outside Stalingrad, which at the moment is held by the Germans. Kerzhentsev, with only two companies of eighteen men each, agrees that the Germans' position, from which they are spraying the Russians with machine-gun fire, needs to be attacked, but he initially balks at the idea of an offensive. ${ }^{29}$ Confident of their success, the colonel reminds the battalion commander, "And that guy, the one who drowns himself at the end, Martin Eden. ... don't give [the book] to anyone. ... If you don't bring it to me, I'll come to you on the knoll to get it" (V okopakh Stalingrada, 168). The offensive is successful, and Kerzhentsev's men gain the hill.

The novel Martin Eden is not mentioned again until about a hundred pages later, when Karnaukhov dies in battle. His body is not found; "someone said they saw him, along with four other soldiers, burst into the German trenches. Apparently he perished in there" - a real Soviet hero. The last time Kerzhentsev sees Karnaukhov, he asks him something and notices that "he raised his head, and for the first time I did not see in his eyes that smile, that deep, quiet smile somewhere in the very depths of his eyes, which I used to like so" (V okopakh Stalingrada, 265, 267). Perhaps Karnaukhov knows that his foray behind German lines, heroic though it might be, will end in his death.

Only twenty-five years old, Karnaukhov doesn't even get a proper burial. But in the narrative, he does get a kind of epitaph, as his love poetry becomes a talisman for Kerzhentsev, who keeps the poem in his pocket along with Lyusya's photo and a letter from his mother. "Simple, clear, pure-just like him. [.. . ] I hang London's portrait on the wall beneath the mirror. They even look a bit alike-London and Karnaukhov" (V okopakh Stalingrada, 266).

Karnaukhov shares with London's Martin Eden a desire for love and poetry, trumped by the knowledge that duty and hard work are more important and must take precedence. When Kerzhentsev first gets to know Karnaukhov, he notes, he liked him immediately. And throughout the novel Karnaukhov continues to demonstrate an admirable quiet bravery.

29 This is an idea first suggested to Kerzhentsev by Karnaukhov: "Oh, how we'd give it to the Fritzes if we took that hill. But what can you do with eighteen men?" The narrator continues, "Karnaukhov is right. If that rise was in our hands, we would make the third battalion's life better, and paralyze the bridge, and have the weapon emplacements that now flank the first battalion. But how to do it?" (Nekrasov, V okopakh Stalingrada, 158). 
In Karnaukhov's case, we have bravery plus duty. Unlike many of the other officers, Karnaukhov not only follows military protocol (bringing daily reports to Kerzhentsev with detailed information on enemy fortifications and arms) but also acts Chapaev-like, one day taking trenches back from the Germans (and "losing only one man"), the next stealing a machine gun and six boxes of bullets from the Germans.

His soldiers said that he himself went after the machine gun, but when I asked him, he smiled and, not looking me in the eye, said that it was only stories, that he'd never allow himself to do such a thing, and that going after machine guns is not what the company commander is for. (V okopakh Stalingrada, 151)

So what is the lesson of Jack London for Kerzhentsev and for the novel? Martin Eden is a heroic figure, but he is no Socialist. Rather, he demonstrates that an individual can be heroic even if he does not subscribe to a particular political ideology, and even if he chooses suicide in the end.

London defended his novel to Upton Sinclair using those very words: "Martin Eden is an individualist, I am a Socialist. That is why I continue to live, and that is the reason why Martin Eden died." Suicide is not a Socialist value. Sinclair noted:

It is easy to understand the befuddlement of critics; for [London] had shown such sympathy with the hard-driving individualist that it would hardly occur to anyone that the character was meant to be a warning and a reproach..$^{30}$

Nekrasov uses Martin Eden to offer his readers an alternative notion of heroism for his readers. Though an approved author for Soviet readers, London created in Martin Eden a hero who emphasizes individualism over the collective and who remains focused on the "I" in choosing to end his own life.

By drawing a parallel between Eden and Karnaukhov, Nekrasov leaves the questions of heroism and duty, love and poetry, the individual and the collective, in a state of ambiguity. Eden and Karnaukhov have positive qualities, but both end up dead. The reader is left to figure out the relationship between the characters and the meaning of their deaths.

30 Upton Sinclair, quoted by Robert Hass, "Introduction," to Jack London, Martin Eden (Toronto: Bantam Books, 1986), xxi. 


\section{Beyond the Trenches}

After the initial success of In the Trenches, Nekrasov wrote several more stories about the war. In all of them he maintained what he saw as the essential tone of everyday life and avoided the heightened rhetoric of heroism. His novel, originally published as Stalingrad, was renamed In the Trenches of Stalingrad, in part to acknowledge that contained within were no "great truths" about the battle as a whole, presented in a historical and panoramic view, but rather the "truth of the trenches," the details of life and byt.

In this way Nekrasov continued to struggle against the standard narrative of war even in the post-war period. For example, one critic praised his demobilization story In My Native Town (V rodnom gorode) thus:

[it is] the first [narrative] to envision the soldiers' homecoming from the front not as an idyll or as a displacement of the battle to the front of Socialist development but realistically as a problem involving the partner who has become a stranger, the mistrustful Party official, the trials of everyday life. ${ }^{31}$

In other words, Nekrasov produced the truth of the postwar world in the same way as he had for the war itself. In this Nekrasov was more successful than Fadeev in his Cement, where those very same problems-the partner who has become a stranger, mistrustful party officials, the trials of everyday life-are precisely portrayed as a "displacement of the battle to the front of Socialist development." We can compare the experiences of Nekrasov's hero to Gleb Chumalov's and see that Nekrasov focused on real experiences and challenges, while Gladkov was enslaved to the rhetoric of podvig.

However, when In My Native Town was to be translated into the genre of film, Nekrasov fought with the director, who argued against that postwar truth:

You must understand that a scenario in which the main character slugs the dean of the college in the face, is then excluded from the party and is not even reinstated by the end of the film, that this kind of scenario doesn't work. If you had shown an officer who returned from the front wounded, who was surrounded by attention and care by everyone: his

31 See Kasack, Dictionary of Russian Literature, 266-267. 
friends, the regional Party Committee, and the Commission for Fatherland War Veterans' Assistance, now that would be a different matter. ... ${ }^{32}$

A different matter indeed. The scenario Nekrasov did not write would have conformed to the canonical rules of socialist realist fiction about war heroes, while the one he did write explored more pressing problems: the problems of mapping military experience and hierarchies onto the frustrations of civilian life.

In the end Nekrasov took his name off the film, and none of the motifs of his story remained. For Nekrasov, the portrayal of the postwar life of soldiers had to explore the conflict between military and civilian life and the psychological repercussions of that conflict, topics and approaches that the director didn't dare to use. Complaining about another film on the topic of adjusting to peacetime, Marlen Khutsiev's The Two Fyodors (1958), one critic wrote, "What kind of hero is that? Depressed, taciturn, unsociable. Do we need a man like that?" Nekrasov believed that such a hero, and such a portrayal, were needed. That's the kind of person Nekrasov himself could believe in.

The struggle over Nekrasov's work was essentially one of tone and detail. While Stalin inexplicably liked and praised In the Trenches of Stalingrad, the author's style was too ordinary, too "real" for socialist realism. Nekrasov was not a teacher; he had no desire to deliver ideologically correct content, especially about the war or about politics. His continual struggles with stereotypes and labels, with the categories of socialist realism and the heroism of war, reflect his more subtle approach to literature and life. ${ }^{33}$ The true Soviet hero has been described as "intelligent, talented, kind, honest, brave, truthful, active, sincere, strong-willed, decisive, self-respecting, unselfish, persistent, trusting, proud, powerful. ..." (Shtut 149). In a word, perfect. Nekrasov was more interested in psychological portrayals of the complexity of man, of the individual, than in producing a character who would inspire the collective with generalized "positive" characteristics.

The decline of Nekrasov's career tracked the way the Cold War settled into Soviet life in the decades of the 1950s and '60s. He never mentioned the Cold War as such, but it played a vital role in shaping his reputation. In 1947 Nekrasov was able to display his complicated set of heroes, a set of heroes that

32 Nekrasov, "Slova 'velikie' i prostye," Iskusstvo kino 5 (1959): 58-59.

33

"More than anything in life, I don't want to teach anyone." See Nekrasov, Zapiski zevaki, 194. 
represents a retreat from the rigid oversimplification of the classic socialist realist novel and from the forced patriotic rhetoric of the typical Soviet war story, but which in decades to come would again prove too complex.

The retreat from socialist realist norms, like the military retreat with which the novel opens, was only temporary. Those "great and beautiful truths" that Panferov called for were not wanted for long, or perhaps the call itself was merely empty rhetoric. Instead, Stalin rapidly changed the course of Soviet war literature and war memory by banning the celebration of Victory Day and suppressing the memory of the war.

Ten years after In the Trenches had been published, the liberty that Nekrasov took with socialist realist prescriptions of heroism was corrected in the film version of the novel. For moviegoers, the heroic emphasis had shifted to Valega, a modernized, more efficient, and more effective version of Chekhov's peasant boy Vanka, a peasant-hero to parallel Vasily Tyorkin. The newly central, simple peasant Valega did not suffer from the ambiguity Kerzhentsev and Karnaukhov noticed in their experience of war. The film was a first step in moving the novel from prizewinning bestseller to suppressed contraband, the beginning of the novel's literary retreat. ${ }^{34}$

In effect, Nekrasov was asked increasingly which side of the barricades he was on. Khrushchev accused Nekrasov of writing like a "tourist with a walking stick," but Nekrasov was more than just a tourist. He may have been an observer, a flâneur, or, as he called himself, a zevaka, but he had also been a participant in the war, and his writing stemmed from those real experiences and the complex psychological reactions they had caused.

Throughout the 1960s, Nekrasov continued to insist, as he had from the very beginning, that he had defended his nation, his people, in the trenches, and he did so in the hopes that children would have the chance to grow up to be poets, musicians, or simply human beings. By the 1970s, that answer would no longer suffice. Under Brezhnev, human beings were not in high demand; the state continued to require heroes and feats, and there was no room for individuals with complex psychological makeups and personal desires.

In a March 5, 1974, letter published in several foreign newspapers, in a calm and rational tone Nekrasov asked, "Who needs this?" "This" was hav-

34 In fact, the film was renamed Soldiers in 1957, although the posters had already been printed up advertising In the Trenches of Stalingrad. "In the end we were ordered to change the name; it was not permitted to use the word Stalingrad." See "VolgogradStalingrad," in Nekrasov, Na voine i posle, 554. 
ing his apartment ransacked, his manuscripts confiscated, and his friends harassed in a continual search for "anti-Soviet materials." What, precisely, Nekrasov wondered, was the definition of anti-Soviet? If the poetry of Marina Tsvetaeva and translations of Pushkin into Hebrew (among the items confiscated) were anti-Soviet, then what about Molotov's October 1939 speech declaring it absurd to fight an idea like Hitlerism? And Beria's speeches? And the millions of people who died under Stalin? Were their deaths pro- or antiSoviet actions?

In the end, Nekrasov had to retreat himself-this time across the border. By the end of 1974, he moved to France, where he continued to observe and write about life in Russia and across the world until his death in 1987. Why did it have to be that way, he asked himself: "People have left, they are leaving, they will leave. ... Why are smart, talented, serious people leaving, people for whom the decision was not easy, people who love their homeland and oh! will miss it terribly?"

Who needs this? The country? The government? The people? Aren't we needlessly discarding people of whom we should be proud? The artist Chagall, the composer Stravinsky, the aeronautical engineer Sikorsky, the writer Nabokov have all become the property of foreign cultures. With whom will we be left? KGB investigators won't create books, paintings or symphonies for us.... ${ }^{35}$

They won't contribute to Russian (or Soviet) culture. Nekrasov continued to insist on the use of "simple words" over "great" ones, and continued to assert the possibility that the ordinary and the great were not mutually exclusive, and in this he continued to fight the rhetoric of podvig, of socialist realist heroism:

There is another kind of language-passionate, but not bombastic, truthful and utilitarian, the language in which ordinary people speak, ordinary people who sometimes achieve great deeds. ${ }^{36}$

That stubborn confidence in the capacity of language to tell the truth may have been most threatening of all to the Soviet state. Nekrasov came to

35 "Komu eto nuzhno," reprinted in Viktor Nekrasov, Kak ia stal sheval'e: Rasskazy. Portrety. Ocherki. Povesti. (Ekaterinburg: U-Faktoriia, 2005), 5-12.

36 Nekrasov, "Slova 'velikie' i prostye," 58, 61. 
that faith through his experience of war, where he committed himself to describing only what he found under his nose, as honestly and compassionately as he knew how.

There is a resonance here, of course, with Ernest Hemingway. Hemingway too went off to war, and what he found most appalling about it was the way it perverted language. It does not exaggerate too much to say that his war experience forced Hemingway to invent a new literary language-a language that would exert an enormous influence on writing in English for the rest of the century, and on Russian writing as well.

After all, when he wasn't being banned, Hemingway was very popular in Russia. ${ }^{37}$ By 1960, for example, there were over one million volumes of Hemingway in Russian circulating around the USSR despite the hiatus in publication of his works between 1939 and 1955 . His popularity was greatest just before the war. Indeed, after Hemingway's suicide in 1961, Soviet writer Ilya Ehrenburg called Hemingway the most popular foreign author in the Soviet Union in the 1930s. ${ }^{38}$

We don't know, and perhaps we can never know, the full extent of the influence of Hemingway's writing on Nekrasov, although Nekrasov is on record for his opinions about Jack London. What we do know is that while the Nazi army advanced on Stalingrad, many Russian writers were thinking of Hemingway. Ilya Ehrenburg read the last pages of A Farewell to Arms aloud at a meeting of the All-Russian Theater Society, and the novel was slated to be published in $1941 .{ }^{39}$ Anna Akhmatova included an epigraph from the novel in the 1942 redaction of her poem "Poem without a Hero." And in 1959when Hemingway became possible again-Nekrasov published another Stalingrad story, "Dedicated to Hemingway." ${ }^{40}$ So in order to think about what

37 See Raisa Orlova, Kheminguei v Rossii: Roman dlinoiu v polstoletiia (Ann Arbor: Ardis, 1985).

38 He said this to an American audience. See Ilya Ehrenburg, "In Memory of Hemingway," Saturday Review 4 (July 1961).

39 It was rumored that Stalin nixed that publication (Orlova, Kheminguei, 30).

40 In this story, the protagonist has the last Hemingway volume (The Fifth Column and 37 Other Stories, 1939) in the trenches at Stalingrad and won't allow it out of his hands; by the end of the story the familiar book is spattered with blood. See Orlova, Kheminguei, 36-37. 
Nekrasov wanted to accomplish, it is worth quoting that famous passage in Hemingway's Farewell to Arms where a lieutenant talks about the relationship between war and language:

I was always embarrassed by the words sacred, glorious, and sacrifice and the expression "in vain". ... I had seen nothing sacred, and the things that were glorious had no glory and the sacrifices were like the stockyards of Chicago if nothing was done with the meat except bury it. There were many words that you could not stand to hear and finally only the names of places had dignity. Certain numbers were the same way and certain dates and these with the names of the places were all you could say and have them mean anything. Abstract words such as glory, honor, courage, or hallowed were obscene beside the concrete names of villages, the numbers of the roads, the names of rivers, the numbers of the regiments and the dates. ${ }^{41}$

Nekrasov too was embarrassed by words like "glory." He tried to introduce a language that would express honestly and with dignity what he had seen in war. It worked, briefly, but it would not be until the 1990s that Russian writers could again describe World War II in a language that was not obscene.

41 Ernest Hemingway, A Farewell to Arms (New York: Scribner Classics, 1997), 169. 